Article

\title{
Evolution of Physico-Chemical Properties, Microbial Biomass and Microbial Activity of an Urban Soil after De-Sealing
}

\author{
Giancarlo Renella \\ Department of Agronomy Food Natural Resources Animals and Environment (DAFNAE), University of Padua, \\ Viale dell’Università 16, 35020 Legnaro, Italy; giancarlo.renella@unipd.it \\ Received: 30 October 2020; Accepted: 28 November 2020; Published: 2 December 2020

\begin{abstract}
Recovery of soil fertility after de-sealing of urban soils is still poorly known. This work studied the time-related dynamics of soil physico-chemical and biochemical endpoints of urban soil in the city in Naples (Southern Italy), de-sealed for different time during construction works, that underwent colonization by volunteer plants. The results showed de-sealing decreased the soil bulk density and the soil $\mathrm{pH}$ value, increased the electrical conductivity (EC), total organic C (TOC) and extractable carbohydrates (TEC), total and inorganic N contents, soil basal respiration (SBR), soil microbial biomass $C(\mathrm{MBC})$ and soil microbial biomass $\mathrm{N}(\mathrm{MBN})$, the substrate induced respiration (SIR) value, and enzyme activities involved in C, N, P and S mineralization. The TEC, total and inorganic N, SBR and microbial biochemical endpoints were higher in the de-sealed soils than those of an arable soil of the same area. The results show that de-sealed urban soils rapidly increase their physical, chemical and biological fertility even with no intervention, especially when they are colonized by volunteer plants.
\end{abstract}

Keywords: urban soil; de-sealed soil; urban soil fertility; soil microbial biomass; soil enzyme activity; soil respiration

\section{Introduction}

Urbanization consumes soil mainly by sealing, and is among the major causes of soil loss in the European Union and worldwide [1]. Sealing of soil by impermeable layers separate it from the atmosphere and hydrosphere [2], reduces its ecological functionality related to water infiltration [3], reduces microbial diversity and microbial activity [4] due to reduced inputs of organic matter [5] and contributes to the adverse effects on urban microclimate [6,7]. Biomass and activity of soil microorganisms depend on the quantitative and qualitative inputs of litter and organic matter, as soil microorganisms obtain energy from their decomposition and mineralization, and the impacts of sealing on soil microbially driven soil functions have been well documented [8].

According to the EU Roadmap to a resource efficient Europe [9], soil is a limited and non-renewable natural resource responsible for multiple ecosystem services, and is an integral part of the natural capital; for these reasons, the EU strategy urges all member States to increase their knowledge on the potential recovery of ecological functionality of impacted urban soils, particularly sealed soils [10]. However, compared to the impact of soil sealing, less is known about the evolution of chemical parameters and biochemical activity of de-sealed soils, which can provide information on the potential of de-sealed soils to gain fertility over time, particularly for those left with no intervention. Fertility is the ability of a soil to support a plant community providing plants with adequate porosity, nutrient levels and microbial activity, and is the soil characteristic needed for restoration interventions of urban areas. Among the soil constituents, soil organic matter (SOM) is the key component quantitatively and 
qualitatively affected by soil sealing and de-sealing. The SOM plays key roles in soil as it stabilizes the soil aggregates increasing soil water-holding capacity, increases the soil buffer capacity of $\mathrm{pH}$ values, and is a reservoir pool of nutrients [11,12]. Therefore, the analysis of the SOM content and C pools can provide indications of the evolution of de-sealed soils. The SOM content and quality depends on the vegetation cover, with grasslands having the most stable SOM contents due to continuous litter and rhizodeposition inputs [13,14]. The SOM sustains the microbial biomass and microbial metabolic activity, and a reduction of SOM generally causes reduction of soil respiration, soil microbial biomass and soil enzyme activity [15-18]. It has been reported that microbial activity and microbial diversity in managed urban soils depends on the age and complexity of the plant communities $[19,20]$, and for this reason, the increase of the soil microbial biomass and microbiological activities have been used biochemical endpoints of increased labile SOM inputs, and more in general of rehabilitation for soils after de-sealing. However, the knowledge of the dynamics of microbial biomass and activity in de-sealed soils, particularly in the early stages of volunteer plant colonization, is still scarce.

The objective of the study was to describe the evolution of key physical, chemical and biological properties of an urban soil de-sealed for different time, undergoing colonization by volunteer plants. I hypothesized that under the action of volunteer plants, de-sealed soils could increase their fertility endpoints to values comparable to those of an agricultural soil, even under no intervention. The results of this study can contribute to a better understanding of the potential induction of fertility in de-sealed urban soils, in the perspective of sustainable urban regeneration practices, in line with the EU Roadmap to a resource efficient Europe [9].

\section{Materials and Methods}

\subsection{Study Area, Soil Sampling and Preparation}

The studied soils are located in Eastern territory of the municipality of Naples (Southern Italy, Latitude 40.8359336, Longitude 14.2487826, 29 m a.s.l.), with Mediterranean Oceanic climate characterized by mean annual rainfall of $952 \mathrm{~mm}$ and average temperature of $17.5^{\circ} \mathrm{C}$. The area underwent urban sprawl beginning in the $1920^{\prime}$ s, and currently has $13 \%$ of its surface covered by roads and railways, $63 \%$ active and dismissed industries, and the remaining surface as residential or used for agriculture. The studied soils are Andosols originated on alluvial sediments and pyroclastic deposits from volcanic parent materials [21], and the area was classified as polluted by the Italian Agency for Environmental Protection due to soil and water pollution by metals and metalloids, polycyclic hydrocarbons (PAH) and polychlorinated hydrocarbons (PCB) causing high incidence of cancer in the population (Law n. 426/1998). Soil samples were taken from an approximately $2 \mathrm{~km}$ long $\times 0.1 \mathrm{~km}$ wide construction site where the surface asphalt layer and gravel were removed from different areas for 2 months (DS2), 20 months (DS20) and 34 (DS34) months. The DS20 and DS34 sampling areas were colonized by volunteer broadleaf plants Amaranthus retroflexus (L.) and Blackstonia perfoliata (L.). The samples were manually taken from selected rectangular areas of $2 \mathrm{~m} \times 5 \mathrm{~m}$ for each sampling area, and 5 samples from $0 \mathrm{~cm}$ to $20 \mathrm{~cm}$ depth using an auger, resulting in 15 independent samples. The soil from a smallholder orchard located $1 \mathrm{~km}$ westbound from the construction site was sampled in 5 points and used for comparing the physico-chemical properties and biochemical activity of the de-sealed soils with those of a fertile soil of the same area. All soils were sampled on the same day, were immediately brought to the analytical laboratories, and each field moist individual soil sample was passed through a $2 \mathrm{~mm}$ sieve. Each sieved soil was then split in two portions of approximately 80 dry weight each: one part was used fresh for the analysis of soil biochemical properties and the other part was air-dried at room temperature and used for the analysis of soil chemical properties. 


\subsection{Analysis of Soil Chemical Properties}

The particle-size distribution was determined using the hydrometer method [22]. The bulk density (BD) was determined using undisturbed soil cores for each sampling area plot taken by a stainless steel cylinder of $50 \mathrm{~cm}^{3}$; the soil cores were saturated with distilled water, then oven-dried at $105^{\circ} \mathrm{C}$, and the difference between the water-saturated and dry soil was used to calculate the BD as the value of the dry soil weight/soil volume ratio value. Soil $\mathrm{pH}$ and electrical conductivity (EC) values were determined using 1:2 soil:water (w:v) suspension by a $\mathrm{pH}$-meter and a conductometer (Metrohm, Herisau, Switzerland). The cation exchange capacity (CEC) was measured using the $1 \mathrm{~N}$ ammonium acetate method [23]. Total C and N were determined with a Carlo Erba C/N 1500 analyzer, the total organic carbon (TOC) was determined by wet the oxidation methods of [24]. Total extractable carbohydrates (TEC) were quantified by extraction of $1 \mathrm{~g}$ of soil shaken with $10 \mathrm{~mL}$ of $1 \mathrm{M} \mathrm{H}_{2} \mathrm{SO}_{4}$ for $16 \mathrm{~h}$ according to [25]. The supernatant solutions were used to determine the carbohydrate concentration using the phenol-sulfuric acid colorimetric method of [26] by UV spectrophotometry (Lambda 2, Perkin Elmer, Waltham, MA, USA), measuring the absorbance of light at $490 \mathrm{~nm}$, and using a calibration curve based on a glucose concentration range of $0-10 \mathrm{mM}$.

\subsection{Measurement of Soil Respiration, Soil Microbial Biomass, Substrate Induced Respiration, and Soil Enzyme Activities}

For measurement of soil basal respiration (SBR) and substrate induced respiration (SIR), the soil samples of $10 \mathrm{~g}$ dry weight equivalent were enclosed in $1 \mathrm{~L}$ air-tight jars along with a vial containing $5 \mathrm{~mL}$ of $0.5 \mathrm{M} \mathrm{NaOH}$ for 4 and 1 day, respectively. For the SIR determination, the soil samples were amended with $1 \mathrm{~mL}$ of glucose solution resulting in a $2 \mathrm{mg}_{\text {glucose- }} \mathrm{C}^{-1}$ dry weight soil [27], whereas the soil samples for the $\mathrm{BR}$ were amended with $1 \mathrm{~mL}$ of distilled water only. The $\mathrm{CO}_{2}-\mathrm{C}$ released by SBR and SIR was quantified by the back titration of $1 \mathrm{M} \mathrm{NaOH}$ against $0.1 \mathrm{M} \mathrm{HCl}$, after $\mathrm{BaCl}_{2}$ carbonate precipitation.

Soil microbial biomass was determined with the fumigation extraction method, specifically microbial biomass $C\left(B_{C}\right)$ according to [28] and microbial biomass $N\left(B_{N}\right)$ according to [29]. The metabolic quotient $\left(\mathrm{qCO}_{2}\right)$ values were determined by the ratio between SBR and $\mathrm{B}_{\mathrm{C}}$ values, and expressed as $\mathrm{mg} \mathrm{CO}_{2} \mathrm{mg} \mathrm{B}_{\mathrm{C}}{ }^{-1}$ day $^{-1}$ [30].

Alkaline and acid phosphatase activities were determined with the method of Tabatabai and Bremner [31], the phosphodiesterase activity according to Browman and Tabatabai [32], the $\beta$-glucosidase activity was measured according to Tabatabai [33]. The urease activity was assayed by the method of Nannipieri et al. [34], and the protease activity using N-benzoylargininamide as substrate [35]. All enzyme activities were assayed at $37^{\circ} \mathrm{C}$ for $1 \mathrm{~h}$, except the protease activity that was assayed for $2 \mathrm{~h}$. Concentrations of 4-nitrophenol (4-NP) produced in the assays of acid and alkaline phosphomonoesterase and phosphodiesterase and $\beta$-glucosidase activities were calculated from the absorbance of light at $400 \mathrm{~nm}$ wavelength by UV/VIS spectrophotometry using a 4-NP calibration curve. The $\mathrm{NH}_{4}{ }^{+}-\mathrm{N}$ released by urease and protease activities was extracted with $1 \mathrm{M} \mathrm{KCl}$ and quantified by spectrophotometry at $660 \mathrm{~nm}$ after reaction with the Nessler reagent.

\subsection{Data Analysis}

Data was analyzed by one-way ANOVA followed by the Fisher PLSD post-hoc test using the Statview software (SAS Institute), and reported as means $(n=5) \pm$ standard deviation. The difference between mean values with a $p$ value $<0.05$ was considered significant.

\section{Results}

\subsection{Soil Chemical Properties}

Main physico-chemical properties of de-sealed and agricultural soils are reported in Table 1. The BD values of the DS2 and DS20 soils were significantly higher than those of the DS34 and AS 
(Table 1). The $\mathrm{pH}$ values of the de-sealed soils showed progressive significant acidification upon increasing of de-sealing time, whereas the arable soil showed a sub-acidic $\mathrm{pH}$ value, with a significantly lower value than that of the de-sealed soils (Table 1). The EC values were significantly higher in the arable as soil compared to the de-sealed soils, and among the latter the DS20 and DS34 soils showed higher values than the DS2 soil (Table 1). The CEC showed significantly higher values for all the de-sealed soils than for the arable soil (Table 1). The TOC and TN contents were higher in the de-sealed soils than in the arable soil, whereas the TEC contents showed higher values in the DS34, followed by DS20 and AS soils with similar values, whereas the DS2 soil showed the lowest TEC value (Table 1). Concerning the $\mathrm{NH}_{4}{ }^{+}-\mathrm{N}$ showed the trend DS2 $>$ DS20 $=$ DS34 $>$ AS, whereas the $\mathrm{NO}_{3}{ }^{-}-\mathrm{N}$ content showed the following trend: DS34 $>$ DS20 $=$ AS $>$ DS2 $($ Table 1$)$. 
Table 1. Main physico-chemical properties of the arable soil and de-sealed soils.

\begin{tabular}{|c|c|c|c|c|c|c|c|c|c|}
\hline Soil & $\begin{array}{c}\text { BD } \\
\left(\mathrm{g} \mathrm{cm}^{-3}\right)\end{array}$ & $\mathrm{pH}$ & $\begin{array}{c}\text { EC } \\
\left(\mu \mathrm{cm}^{-1}\right)\end{array}$ & $\begin{array}{c}\text { CEC } \\
\left(\mathrm{cmol} \mathrm{kg}^{-1}\right)\end{array}$ & $\begin{array}{c}\text { TOC } \\
\left(\mathrm{g} \mathrm{kg}^{-1}\right)\end{array}$ & $\begin{array}{c}\text { TEC } \\
\left(\mathrm{g} \mathrm{kg}^{-1}\right)\end{array}$ & $\begin{array}{c}\mathrm{TN} \\
\left(\mathrm{g} \mathrm{kg}^{-1}\right)\end{array}$ & $\begin{array}{c}\mathrm{NH}_{4}{ }^{-}-\mathrm{N} \\
\left(\mathrm{g} \mathrm{kg}^{-1}\right)\end{array}$ & $\begin{array}{l}\mathrm{NO}_{3}^{--N} \\
\left(\mathrm{~g} \mathrm{~kg}^{-1}\right)\end{array}$ \\
\hline AS & $1.05 \pm 0.04^{\mathrm{c}}$ & $6.85 \pm 0.03^{d}$ & $230 \pm 11.9^{a}$ & $22.9 \pm 0.92^{a}$ & $12.2 \pm 0.31^{\mathrm{c}}$ & $703 \pm 28.1^{b}$ & $1.01 \pm 0.06^{c}$ & $4.73 \pm 0.29^{c}$ & $29.7 \pm 3.90^{b}$ \\
\hline DS2 & $1.25 \pm 0.05^{\mathrm{a}}$ & $7.20 \pm 0.03^{a}$ & $164 \pm 5.63^{c}$ & $18.6 \pm 0.95^{b}$ & $17.2 \pm 0.24^{b}$ & $302 \pm 13.2^{c}$ & $1.22 \pm 0.06^{b}$ & $6.57 \pm 0.31^{a}$ & $22.3 \pm 1.04^{d}$ \\
\hline DS20 & $1.16 \pm 0.02^{b}$ & $7.12 \pm 0.02^{b}$ & $192 \pm 10.1^{b}$ & $19.0 \pm 0.68^{b}$ & $17.1 \pm 0.29 b$ & $745 \pm 50.6^{b}$ & $1.30 \pm 0.04^{\mathrm{a}}$ & $5.84 \pm 0.24^{b}$ & $33.0 \pm 1.30^{b}$ \\
\hline DS34 & $1.09 \pm 0.05^{\mathrm{c}}$ & $7.05 \pm 0.03^{c}$ & $194 \pm 7.44^{b}$ & $19.0 \pm 0.80^{b}$ & $17.6 \pm 0.41^{b}$ & $1010 \pm 52.3^{a}$ & $1.29 \pm 0.03^{\mathrm{a}}$ & $5.71 \pm 0.40^{b}$ & $40.0 \pm 3.33^{\mathrm{a}}$ \\
\hline
\end{tabular}

BD-Bulk density; EC—Electrical conductivity; CEC—Cation exchange capacity; TOC—Total organic carbon; TEC—Total extractable carbohydrates; TN-Total nitrogen. Values are the means of 5 replicates \pm the standard deviation. Different superscripts among mean values of each row indicate significant differences $(p<0.05)$. 


\subsection{Soil Respiration, Soil Microbial Biomass, SIR, and Soil Enzyme Activities}

The SBR and SIR values were significantly higher in the DS34 and DS20 soils than in the DS2 and AS soils, whereas the DS2 soil showed the lowest SBR values (Table 2). After subtraction of the of the SIR by the SBR values, the glucose-derived C amounted to $47 \%$ for the DS34, 36\% for the DS20, 34\% for the AS and $21 \%$ for the DS2 soils. The highest $B_{C}$ content was found in the DS34 soil followed by DS20 and AS soils which had similar values, whereas the $B_{C}$ content was found in the DS2 soil (Table 2). The $B_{N}$ values showed the similar ranking, except that the DS20 soil showed a higher value that of the AS soil (Table 2). The $\mathrm{qCO}_{2}$ values showed higher values in the DS34 soil followed by the DS20, AS and DS2 soils, whereas the $B_{C}$-to-TOC ratio values showed higher values in the DS2, followed by DS34 and DS20 soils with similar values, followed by the AS and soil showing the lowest value (Table 2).

Table 2. Basal respiration of the arable soil and de-sealed soils.

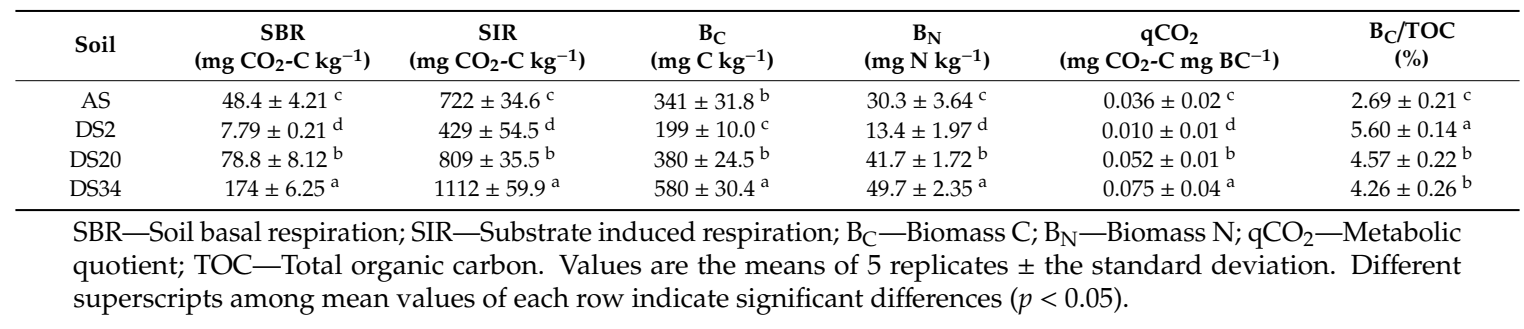

The DS34 and the DS2 soils showed the highest and the lowest values for all the measured enzyme activities, respectively (Figure 1). For the other two analyzed soils, the DS20 showed higher values of the alkaline and acid phosphatase activities than the AS soil, while the AS soil showed higher protease, urease and $\beta$-glucosidase activities than the DS20 soil, and the phosphodiesterase and arylsulfatase activities showed similar values in the two soils (Figure 2).

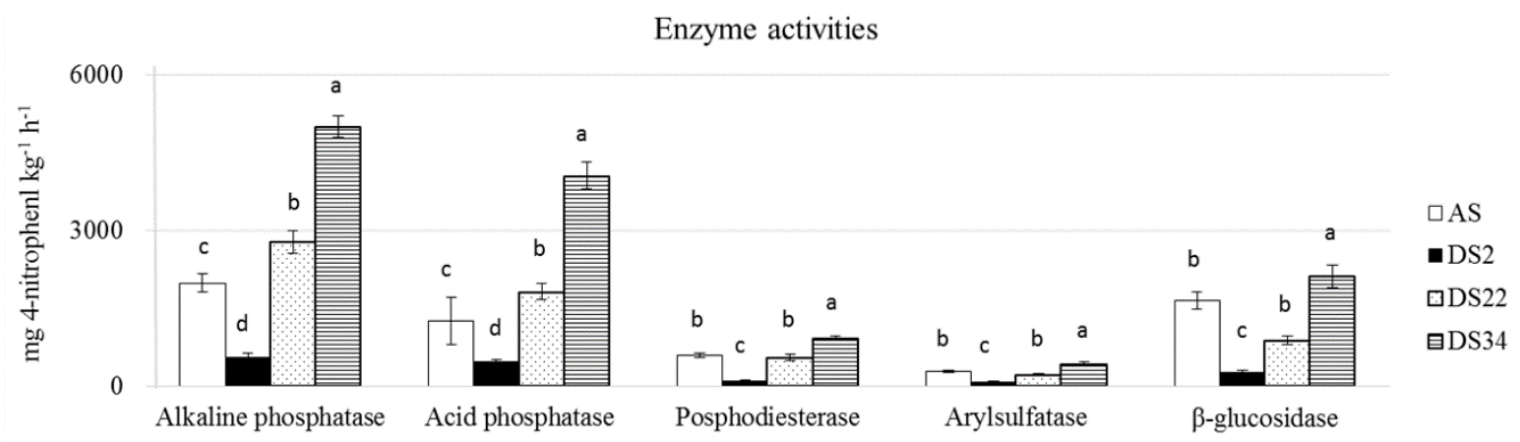

(a)

Figure 1. Cont. 


\section{Enzyme activities}

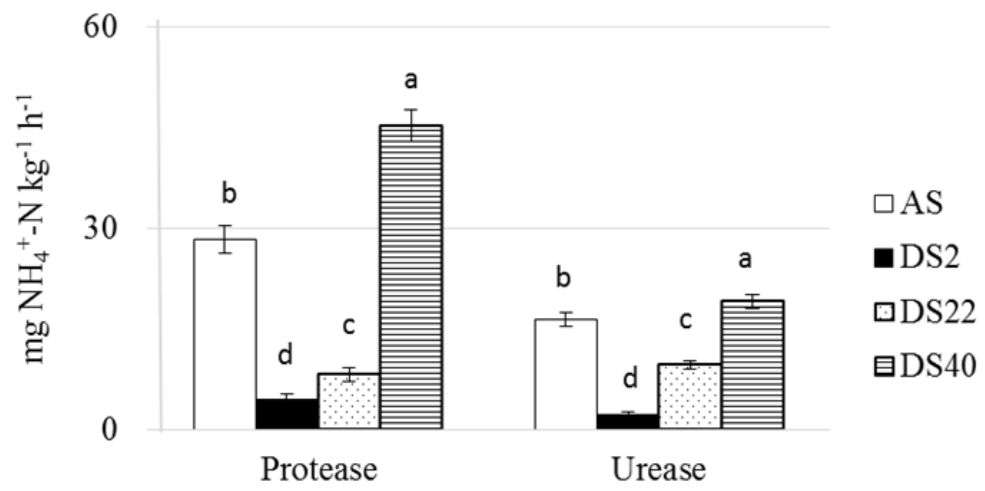

Enzyme actvities

(b)

Figure 1. Enzyme activities of the arable soil (a) and de-sealed soils (b). For each enzyme activity, different superscripts indicate significant differences $(p<0.05)$ between the mean values $(n=5)$.
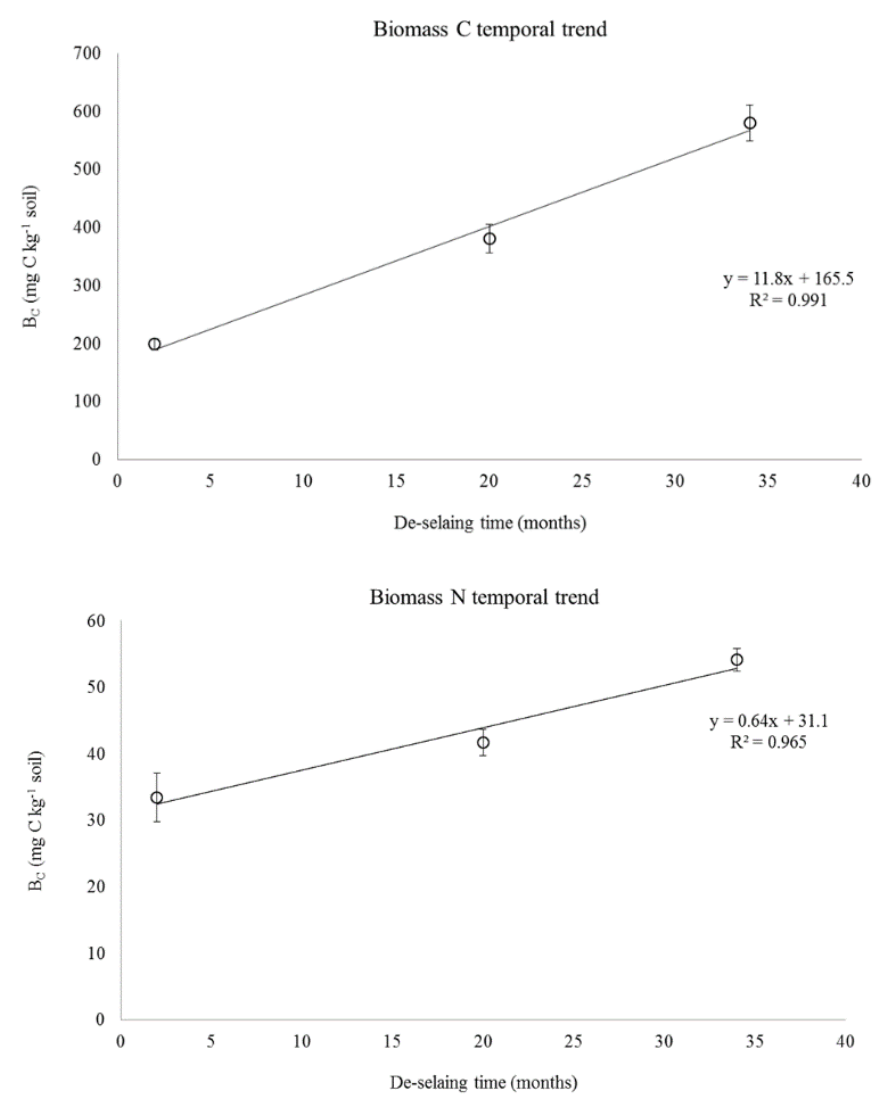

Figure 2. Trend of the microbial biomass $C$ in soil de-sealed for 2, 20 and 34 months. The error bar represents the standard deviation of the mean values $(n=5)$.

\section{Discussion}

De-sealing for increasing times led to a significant decrease the soil BD, likely due to the surface colonization by volunteer plants, indicating a reduced soil compaction and an improved soil structure, factors of prime importance for the rehabilitation of soil ecological functions [36]. Improved structure of the soil and plant colonization were likely joint factors influencing the $\mathrm{C}$ and $\mathrm{N}$ pools, particularly the increased TEC and $\mathrm{NO}_{3}{ }^{-}-\mathrm{N}$ content of the de-sealed soils upon time (Table 1). With the rhizodepositions 
in fact, plants release sugars, amino acids, low molecular weight organic acids and phenolics, along with sloughed cells and mucigels, which are rapidly mineralized by soil microorganisms, thus sustaining a larger and more active microbial community in the plant rhizosphere [37]. The TEC results support the previous finding that forest soils contain significantly higher carbohydrate content than arable soil [38]. Decomposition of rhizodepositions and TEC led the significant acidification of the DS34 and DS20 soils as compared to the DS2 soil, owing to the production of $\mathrm{H}^{+}$and nitrification activity, as previously reported for a plant colonization chronosequence [39]. Increase in TEC, CEC and $\mathrm{NO}_{3}{ }^{-}-\mathrm{N}$ of DS20 and DS34 soils as compared to the DS2 soil was in line with data reported for a rhizosphere soil during a vegetation chronosequence [40].

Enrichment of the de-sealed soils with labile $C$ resulted in increased basal respiration, total microbial biomass and fungal biomass sustained by fresh inputs of plant debris into soil [41], and the increases of $\mathrm{BR}, \mathrm{MBC}$, and $\mathrm{MBN}$ were in agreement with previous reports [42]. The increase of microbial activity was also reflected in the higher SIR response and higher soil enzyme activities with increasing of de-sealing time, as well as the higher $\mathrm{qCO}_{2}$ values observed in the DS34 and DS20 as compared to the DS2 soil (Table 1, Figure 1). The $\mathrm{B}_{\mathrm{C}} / \mathrm{TOC}$ ratio values showed typical previously reported values for the AS [43], whereas the significantly higher values of the DS soils indicated an accumulation in the sealed soils due to reduced SOM decomposition. In this study, the $\mathrm{B}_{\mathrm{C}} / \mathrm{TOC}$ ratio values were $3.2 \%$ for the DS34, $2.8 \%$ for the AS, $2.2 \%$ for the DS20 and $0.9 \%$ for the DS2 soils. Average $\mathrm{B}_{\mathrm{C}} / \mathrm{TOC}$ ratio value of arable and forest soils are in the range 1-5\% [44], and it varies only in soils after fresh organic inputs [45]. Soil $B_{C}$ and $B_{N}$ values of urban soils are profoundly influenced by soil physical properties such as water infiltration soil temperature, concentration of nutrients and pollutants, and in urban soils human disturbance leads to altered values and wide fluctuations as compared to agricultural soil $[46,47]$.

The metabolic quotient $\left(\mathrm{qCO}_{2}\right)$ values of the DS soils significantly increased upon increasing of de-sealing time (Table 2). Increased $\mathrm{qCO}_{2}$ values have been often as indicators of a stress response of soil microorganisms leading to a lower $\mathrm{C}$ use efficiency caused by microbial selection or energy diversion in the microbial community from cell proliferation to repair of cell damages [48]. However, while this interpretation can be valid for long-term impacted soils under steady state, it is unlikely to apply to the present study. In fact, the studied de-sealed soils could be considered still under evolution upon colonization by volunteer plants, in which soil microorganisms could still increase in biomass and diversity upon soil enrichment of plant-borne labile $C$. This was confirmed by the linear increase of $B_{C}$ and $B_{N}$ with time (Figure 2). In this sense, the DS34 and DS20 soils could be considered as energy rich ecological habitats under microbial colonization sustained by plant rhizodepositions. Kuzyakov and Domanski [49] reported that up to $20 \%$ of C assimilated by young plants of wheat, barley, or grasses could be retrieved in the SOM pool available to soil microorganisms, and even higher percentages have been reported using ${ }^{14} \mathrm{C}$-labeling techniques of rhizodepositions [50]. Therefore, the significantly higher $\mathrm{qCO}_{2}$ values found in the DS soils upon increasing of the de-sealing time reflected proliferation of soil microorganisms [51]. Overall, this microbial anabolic mechanism is at the basis of the microbial $C$ pump mechanism [52] that can lead to $C$ stabilization and sequestration in de-sealed revegetated soils.

Among the measured soil enzyme activities, higher protease and urease activities catalyzing organic $\mathrm{N}$ mineralization could explain the increased $\mathrm{NO}_{3}{ }^{-}-\mathrm{N}$ content of the DS34 and DS20 soils, as the release of ammonia- $\mathrm{N}$ in well aerated soils generally fuels the nitrification [53]. Increase of $\beta$-glucosidase activity upon soil revegetation confirms previous reports, showing that this enzyme activity is generally higher high in grassland soils [54,55], and is an indicator of soil quality [56], and the general increase of soil enzyme activities in involved in C, N, P and S cycles in the DS34 and DS20 soils to higher or equivalent levels to those of an agricultural soil could be ascribed to the increase of labile $\mathrm{C}$ (TEC) content and higher microbial biomass and metabolic activity [57]. 


\section{Conclusions}

Soil de-sealing improved their physical and chemical fertility in a relatively short time, and increased the soil microbial biomass and biochemical activity to levels comparable or higher than those of an agricultural soil of the same area. Such an improvement occurred with no intervention and was favored by the colonization by volunteer plants that allocated labile $C$ into soil. These results can contribute to the recent growing interest in assessing the quality of urban soils and support the hypothesis that soil de-sealing, even followed by plant colonization, improve soil ecosystem services and quality of the urban environment while storing $C$ in soil.

Funding: This research received no external funding.

Conflicts of Interest: The authors declare no conflict of interest.

\section{References}

1. EEA. European Environmental Agency. Signals 2019-Land and Soil in Europe; EEA Report No 2443-7662; Office of the European Union: Luxembourg, 2019; p. 60. ISBN 978-92-9480-095-4.

2. Burghardt, W. Main characteristics of urban soils. In Soils Within Cities-Global Approaches to Their Sustainable Management-Composition, Properties, and Functions of Soils of the Urban Environment; Levin, M.J., Khj, K., Morel, J.L., Burghardt, W., Charzynski, P., Shaw, R.K., Eds.; Schweizerbart Soil Sciences: Stuttgart, Germany, 2017; pp. 19-26.

3. Bhaduri, B.; Minner, M.; Tatalovich, S.; Harbor, J. Long-term hydrologic impact of urbanization: A tale of two models. J. Water Res. Plan. Manag. 2001, 127, 13-19. [CrossRef]

4. Hu, Y.; Dou, X.; Li, J.; Li, F. Impervious Surfaces Alter Soil Bacterial Communities in Urban Areas: A Case Study in Beijing, China. Front. Microbiol. 2018, 9, 226. [CrossRef] [PubMed]

5. Lu, C.; Kotze, D.J.; Setälä, H.M. Environment Soil sealing causes substantial losses in C and N storage in urban soils under cool climate. Sci. Total Environ. 2020, 725, 138369. [CrossRef]

6. Fokaides, P.A.; Kylili, A.; Nicolaou, L.; Byron Ioannou, B. The effect of soil sealing on the urban heat island phenomenon. Indoor Built Environ. 2016, 25, 1136-1147. [CrossRef]

7. Murata, T.; Kawai, N. Degradation of the urban ecosystem function due to soil sealing: Involvement in the heat island phenomenon and hydrologic cycle in the Tokyo metropolitan area. Soil Sci. Plant Nutr. 2018, 64, 145-155. [CrossRef]

8. Piotrowska-Długosz, A.; Charzyński, P. The impact of the soil sealing degree on microbial biomass, enzymatic activity, and physicochemical properties in the Ekranic Technosols of Torun (Poland). J. Soils Sediments 2015, 15, 47-59. [CrossRef]

9. European Commission (EC). Communication from the Commission to the Parliament, the Council, the European Economic and Social Committee and the Committee of the Regions. Roadmap to a Resource Efficient Europe. COM (2011) 571 Final, Brussels, 20.9.2011. 2011. Available online: https://eur-lex.europa. eu/legal-content/EN/TXT/PDF/?uri=CELEX:52011DC0571\&from=EN (accessed on 30 October 2020).

10. European Environmental Agency (EEA). Soil Resource Efficiency in Urbanised Areas. Analytical Framework and Implications for Governance; EEA Report No 7/2016; Office of the European Union: Luxembourg, 2016 ; p. 90. ISBN 978-92-9213-730-4.

11. Christensen, B.T. Carbon in primary and secondary organomineral complexes. In Structure and Organic Matter Storage in Agricultural Soils; Carter, M.R., Stewart, B.A., Eds.; Advances in Soil Science, CRC Lewis Publilshers: Boca Raton, FL, USA, 1996; pp. 97-165.

12. Stockmann, U.; Padarian, J.; McBratney, A.; Minasny, B.; De Brogniez, D.; Montanarella, L.; Hong, S.Y.; Rawlins, B.G.; Field, D.J. Global soil organic carbon assessment. Glob. Food Secur. 2015, 6, 9-16. [CrossRef]

13. Malhi, Y.; Meir, P.; Brown, S. Forests, carbon and global climate. Philos. Trans. R. Soc. A Math. Phys. Eng. Sci. 2002, 360, 1567-1591. [CrossRef]

14. Dlamini, P.; Chivenge, P.; Manson, A.; Chaplot, V. Land degradation impact on soil organic carbon and nitrogen stocks of sub-tropical humid grasslands in South Africa. Geoderma 2014, 235, 372-381. [CrossRef] 
15. Mangalassery, S.; Mooney, S.J.; Sparkes, D.; Fraser, W.; Sjogersten, S. Impacts of zero tillage on soil enzyme activities, microbial characteristics and organic matter functional chemistry in temperate soils. Eur. J. Soil Biol. 2015, 68, 9-17. [CrossRef]

16. Vinhal-Freitas, I.C.; Corrêa, G.F.; Wendling, B.; Bobul'ská, L.; Ferreira, A.S. Soil textural class plays a major role in evaluating the effects of land use on soil quality indicators. Ecol. Indic. 2017, 74, 182-190. [CrossRef]

17. Saikia, R.; Sharma, S.; Thind, H.; Sidhu, H.; Singh, Y. Temporal changes in biochemical indicators of soil quality in response to tillage, crop residue and green manure management in a rice-wheat system. Ecol. Indic. 2019, 103, 383-394. [CrossRef]

18. Van Leeuwen, J.; Djukic, I.; Bloem, J.; Lehtinen, T.; Hemerik, L.; De Ruiter, P.; Lair, G. Effects of land use on soil microbial biomass, activity and community structure at different soil depths in the Danube floodplain. Eur. J. Soil Biol. 2017, 79, 14-20. [CrossRef]

19. Hui, N.; Jumpponen, A.; Francini, G.; Kotze, D.J.; Liu, X.; Romantschuk, M.; Strömmer, R.; Setälä, H. Soil microbial communities are shaped by vegetation type and park age in cities under cold climate. Environ. Microbiol. 2017, 19, 1281-1295. [CrossRef]

20. Francini, G.; Hui, N.; Jumpponen, A.; Kotze, D.; Romantschuk, M.; Allen, J.; Setälä, H. Soil biota in boreal urban greenspace: Responses to plant type and age. Soil Biol. Biochem. 2018, 118, 145-155. [CrossRef]

21. Costantini, E.A.C.; L'Abate, G.; Barbetti, R.; Fantappié, M.; Lorenzetti, R.; Magini, S. Carta dei suoli d'Italia; Consiglio per Ricerca e la Sperimentazione in Agricoltura (CREA), Ministero delle Politiche Agricole Alimentari e Forestali: Rome, Italy, 2012. Available online: https://esdac.jrc.ec.europa.eu/content/carta-deisuoli-ditalia-soil-map-italy (accessed on 30 October 2020).

22. Gee, G.W.; Bauder, J.W. Particle-size analysis. In Methods of Soil Analysis, 2nd ed.; Klute, A., Ed.; Agronomical Monographs; American Society of Agronomy and Soil Science Society of America: Madison, WI, USA, 1986; Volume 9, pp. 383-411.

23. Summer, M.E.; Miller, W.P. Cation exchange capacity and exchange coefficients. In Methods of Soil Analysis, Part 3 Chemical Methods; Sparks, D.L., Page, A.L., Helmke, P.A., Loeppert, R.H., Soltanpour, P.N., Tabatabai, M.A., Johnston, C.T., Sumner, M.E., Eds.; Soil Science Society of America: Madison, WI, USA, 1996; pp. 1201-1229.

24. Walkley, A.; Black, I.A. An Examination of the Degtjareff Method for Determining Soil Organic Matter, and a Proposed Modification of The Chromic Acid Titration Method. Soil Sci. 1934, 37, 29-38. [CrossRef]

25. Piccolo, A.; Zena, A.; Conte, P. A comparison of acid hydrolyses for the determination of carbohydrate content in soils. Commun. Soil Sci. Plant. Anal. 1996, 27, 2909-2915. [CrossRef]

26. Dubois, M.; Gilles, K.A.; Hamilton, J.K.; Rebers, P.A.; Smith, F. Colorimetric Method for Determination of Sugars and Related Substances. Anal. Chem. 1956, 28, 350-356. [CrossRef]

27. Anderson, J.; Domsch, K. A physiological method for the quantitative measurement of microbial biomass in soils. Soil Biol. Biochem. 1978, 10, 215-221. [CrossRef]

28. Vance, E.; Brookes, P.; Jenkinson, D. An extraction method for measuring soil microbial biomass C. Soil Biol. Biochem. 1987, 19, 703-707. [CrossRef]

29. Brookes, P.C.; Landman, A.; Pruden, G.; Jenkinson, D.S. Chloroform fumigation and the release of soil nitrogen: A rapid direct extraction method for measuring microbial biomass nitrogen in soil. Soil Biol. Biochem. 1985, 17, 837-842. [CrossRef]

30. Anderson, T.-H.; Domsch, K. The metabolic quotient for $\mathrm{CO}_{2}\left(\mathrm{qCO}_{2}\right)$ as a specific activity parameter to assess the effects of environmental conditions, such as ph, on the microbial biomass of forest soils. Soil Biol. Biochem. 1993, 25, 393-395. [CrossRef]

31. Tabatabai, M.A.; Bremner, J.M. Use of p-nitrophenil phosphate for assay of soil phosphatase activity. Soil Biol. Biochem. 1969, 1, 301-307. [CrossRef]

32. Browman, M.G.; Tabatabai, M.A. Phosphodiesterase activity of soils. Soil. Sci. Soc. Am. J. 1978, 42, $284-290$. [CrossRef]

33. Tabatabai, M. Soil enzymes. In Methods of Soil Analysis: Part 2 Chemical and Microbiological Properties; Page, A.L., Miller, E.M., Keeney, D.R., Eds.; American Society of Agronomy-Soil Science Society of America: Madison, WI, USA, 1982; pp. 903-947.

34. Nannipieri, P.; Johnson, R.L.; Paul, E.A. Criteria for measuring microbial growth and activity in soil. Soil Biol. Biochem. 1978, 10, 223-229. [CrossRef]

35. Ladd, J.; Butler, J. Short-term assays of soil proteolytic enzyme activities using proteins and dipeptide derivatives as substrates. Soil Biol. Biochem. 1972, 4, 19-30. [CrossRef] 
36. Rabot, E.; Wiesmeier, M.; Schlüter, S.; Vogel, H.J. Soil structure as an indicator of soil functions: A review. Geoderma 2018, 314, 122-137. [CrossRef]

37. Neumann, G.; Römheld, V. Rhizosphere Chemistry in Relation to Plant Nutrition. In Marschner's Mineral Nutrition of Higher Plants; Elsevier BV: Amsterdam, The Netherlands, 2012; pp. 347-368.

38. Bongiovanni, M.D.; Lobartini, J. Particulate organic matter, carbohydrate, humic acid contents in soil macroand microaggregates as affected by cultivation. Geoderma 2006, 136, 660-665. [CrossRef]

39. Jussy, J.-H.; Colin-Belgrand, M.; Ranger, J. Production and root uptake of mineral nitrogen in a chronosequence of Douglas-fir (Pseudotsuga menziessii) in the Beaujolais Mounts. Forest Ecol. Manag. 2000, 128, 197-209. [CrossRef]

40. Marques, R.; Ranger, J.; Villette, S.; Granier, A. Nutrient dynamics in a chronosequence of Douglas-fir (Pseudotsuga menziesii (Mirb). Franco) stands on the Beaujolais Mounts (France). 2. Quantitative approach. For. Ecol. Manag. 1997, 92, 167-197. [CrossRef]

41. Raiesi, F.; Asadi, E. Soil microbial activity and litter turnover in native grazed and ungrazed rangelands in a semiarid ecosystem. Biol. Fertil. Soils 2006, 43, 76-82. [CrossRef]

42. Frank, A.; Liebig, M.; Tanaka, D. Management effects on soil $\mathrm{CO}_{2}$ efflux in northern semiarid grassland and cropland. Soil Tillage Res. 2006, 89, 78-85. [CrossRef]

43. Anderson, T.-H.; Domsch, K. Ratios of microbial biomass carbon to total organic carbon in arable soils. Soil Biol. Biochem. 1989, 21, 471-479. [CrossRef]

44. Sparling, G. Ratio of microbial biomass carbon to soil organic carbon as a sensitive indicator of changes in soil organic matter. Soil Res. 1992, 30, 195-207. [CrossRef]

45. Beyer, L. Soil microbial biomass and organic matter composition in soils under cultivation. Biol. Fertil. Soils 1995, 19, 197-202. [CrossRef]

46. Lorenz, K.; Kandeler, E. Microbial biomass and activities in urban soils in two consecutive years. J. Plant Nutr. Soil. Sci. 2006, 169, 799-808. [CrossRef]

47. Kissling, M.; Hegetschweiler, K.T.; Rusterholz, H.-P.; Baur, B. Short-term and long-term effects of human trampling on above-ground vegetation, soil density, soil organic matter and soil microbial processes in suburban beech forests. Appl. Soil Ecol. 2009, 42, 303-314. [CrossRef]

48. Brookes, P.C. The use of microbial parameters in monitoring soil pollution by heavy metals. Biol. Fertil. Soils 1995, 19, 269-279. [CrossRef]

49. Kuzyakov, Y.; Domanski, G. Carbon input by plants into the soil. Rev. J. Plant Nutr. Soil Sci. 2000, 163, 421-431. [CrossRef]

50. Lynch, J.M.; Whipps, J.M. Substrate flow in the rhizosphere. Plant Soil 1990, 129, 1-10. [CrossRef]

51. Pirt, S.J. Principles of Microbe and Cell Cultivation; Blackwell Scientific Publication: Oxford, UK, 1975 ; p. 274.

52. Liang, C.; Schimel, J.P.; Jastrow, J.D. The importance of anabolism in microbial control over soil carbon storage. Nat. Microbiol. 2017, 2, 17105. [CrossRef]

53. Coskun, D.; Britto, D.T.; Shi, W.; Kronzucker, H.J. Nitrogen transformations in modern agriculture and the role of biological nitrification inhibition. Nat. Plants 2017, 3, 17074. [CrossRef]

54. Eivazi, F.; Tabatabai, M. Glucosidases and galactosidases in soils. Soil Biol. Biochem. 1988, 20, 601-606. [CrossRef]

55. Delelegn, Y.T.; Purahong, W.; Blazevic, A.; Yitaferu, B.; Wubet, T.; Göransson, H.; Godbold, D.L. Changes in land use alter soil quality and aggregate stability in the highlands of northern Ethiopia. Sci. Rep. 2017, 7, 1-12. [CrossRef]

56. Knight, T.R.; Dick, R.P. Differentiating microbial and stabilized $\beta$-glucosidase activity relative to soil quality. Soil Biol. Biochem. 2004, 36, 2089-2096. [CrossRef]

57. Bandick, A.K.; Dick, R.P. Field management effects on soil enzyme activities. Soil Biol. Biochem. 1999, 31, 1471-1479. [CrossRef]

Publisher's Note: MDPI stays neutral with regard to jurisdictional claims in published maps and institutional affiliations. 